\title{
In vitro and in vivo efficacy of edelfosine-loaded lipid nanoparticles against glioma
}

Ander Estella-Hermoso de Mendoza ${ }^{1}$, Veronique Préat ${ }^{2}$, Faustino Mollinedo ${ }^{3}$, María J. Blanco-Prieto $^{1}$

${ }^{1}$ Department of Pharmacy and Pharmaceutical Technology, School of Pharmacy, University of Navarra, E-31008, Spain, ${ }^{2}$ Université Catholique de Louvain, Louvain Drug Research Institute, Pharmaceutics and drug delivery, Avenue Mounier, 73 UCL B1 73.12, 1200 Brussels, Belgium, ${ }^{3}$ Instituto de Biología Molecular y Celular del Cáncer, Centro de Investigación del Cáncer, Consejo Superior de Investigaciones Científicas (CSIC) Universidad de Salamanca, Campus Miguel de Unamuno, E-37007 Salamanca, Spain

Corresponding author: María J. Blanco-Prieto, PhD, Department of Pharmacy and Pharmaceutical Technology, School of Pharmacy, University of Navarra, C/Irunlarrea 1, E31080 Pamplona, Spain, Office phone: + 34948425600 ext. 6519, Fax: + 34948425 649, e-mail: mjblanco@unav.es 


\section{Abstract}

Edelfosine is the prototype molecule of a family of anticancer drugs collectively known as synthetic alkyl-lysophospholipids. This drug holds promise as a selective antitumor agent, and a number of preclinical assays are in progress. In this study, we observe the accumulation of edelfosine in brain tissue after its oral administration in Compritol $^{\circledR}$ and Precirol ${ }^{\circledR}$ lipid nanoparticles (LN). The high accumulation of edelfosine in brain was due to the inhibition of P-glycoprotein by Tween ${ }^{\circledR} 80$, as verified using a P-glycoprotein drug interaction assay. Moreover, these LN were tested in vitro against the $\mathrm{C} 6$ glioma cell line, which was later employed to establish an in vivo xenograft mouse model of glioma. In vitro studies revealed that edelfosine-loaded LN induced an antiproliferative effect in C6 glioma cell line. In addition, in vivo oral administration of drug-loaded LN in NMRI nude mice bearing a C6 glioma xenograft tumor induced a highly significant reduction in tumor growth $(p<0.01)$ fourteen days after the beginning of the treatment. Our results showed that Tween ${ }^{\circledR} 80$ coated Compritol $^{\circledR}$ and Precirol ${ }^{\circledR}$ LN can effectively inhibit the growth of C6 glioma cells in vitro and suggest that edelfosine-loaded LN represent an attractive option for the enhancement of antitumor activity on brain tumors in vivo.

Key Words: edelfosine, glioma, lipid nanoparticles 


\section{Introduction}

Brain targeting has posed a great challenge throughout the history of therapeutics. Drug delivery to the brain is rigorously controlled by the blood brain barrier (BBB), which represents an overwhelming obstacle for many essential drugs including cytotoxics, antibiotics or central nervous system (CNS) active drugs [1]. The BBB is the homeostatic mechanism of defense of the brain against toxic molecules and pathogens. This exclusive membrane is formed by special endothelial cells sealed with tight junctions, which hamper the way into the brain from the bloodstream of many compounds that might be of therapeutic value in the treatment of a great assortment of pathologies $[2,3]$. These issues, along with poor knowledge regarding the physiology of the CNS, have been the main limiting factors in the development of effective drugs and appropriate drug delivery systems (DDS) for brain targeting [1, 4-7]. In order for a drug to reach a target within the brain, some drawbacks that hinder its way must be taken into account. Among other factors, the drug must overcome the weak permeability of the BBB separating the blood vessels from the cerebral parenchyma [8] or the BBB active drug efflux transporters that are widely present in the cerebral endothelium and play an important role in the efflux mechanism of a wide variety of drugs [9].

Gliomas are the most common primary brain tumors [10], glioblastoma multiforme being the most aggressive subtype. The prognosis for patients with glioblastoma is poor, with a median survival of less than a year. The failure of chemotherapy in glioma patients is often due to the development of resistance by tumor cells and the difficulty of ensuring that drugs cross the BBB. Multidrug resistance (MDR) effect is due to the overexpression of membrane-bound proteins that efflux drugs from the cells, resulting in decreased intracellular drug concentration [11]. These drug efflux proteins are expressed not only in the BBB but also in brain glioma cells $[12,13]$. Therefore, these proteins restrain the transport of the drug across the BBB, and decrease intracellular drug concentrations inside the brain gliomas via efflux.

Lipid nanoparticles (LN) have arisen in the last ten years as promising colloidal systems for the delivery of drugs to several diseases of the central nervous system, including tumors, as they are able to bypass the drawbacks mentioned above [14-16].

In a previous study we showed that the alkyl-lysophospholipidic antitumor drug edelfosine presents a wide distribution through the organism after multiple oral administration of the drug in solution, presenting a higher affinity for tumor tissue as well as kidney and intestine, and showing very low absorption after single oral administrations [17]. Conversely, after a single oral administration of edelfosine-loaded $\mathrm{LN}$, the drug was absorbed in the gastrointestinal tract and had high concentrations in plasma (Estella-Hermoso de Mendoza et al., submitted). Unlike different polymeric or liposomal systems, these LN are obtained by a solvent-free process and are physicochemically stable [18]. Besides, the Tween ${ }^{\circledR} 80$ included within the LN shell inhibits the P-gp efflux pump [19, 20].

The objective of the present study was to evaluate the possibility of brain targeting with LN after their administration by the oral route and to assess their efficacy, both in vitro against a rat glioma cell line and in vivo in a glioma-bearing xenograft mouse animal model.

\section{Materials and Methods \\ 2.1 Chemicals}

Edelfosine was from APOINTECH (Salamanca, Spain). Compritol ${ }^{\circledR} 888$ ATO and Precirol $^{\circledR}$ ATO 5 were a gift from Gattefossé (Lyon, France). Tween ${ }^{\circledR} 80$ was obtained from Roig Farma (Barcelona, Spain). 3-(4, 5-dimethylthiazol-2-yl)-2,5-diphenyl 
tetrazolium bromide) (MTT), Platelet Activating Factor (PAF) and PBS (10 mM phosphate, $0.9 \% \mathrm{NaCl}$ ) were obtained from Sigma-Aldrich (St. Louis, MO, USA). Chloroform was purchased from Panreac (Madrid, Spain) and methanol was obtained from Merck (Barcelona, Spain). All solvents employed for the analysis were of analytical grade. C6 (rat glioma) cells were purchased from ATCC (American Type Culture Collection, Manassas, VA, USA). Dubelcco's modified Eagle's medium (DMEM), heat-inactivated fetal bovine serum (FBS), trypsin-EDTA and penicillinstreptomycin mixtures were from Gibco ${ }^{\circledR}$ BRL (Carlsbad, CA, USA). Ultra-purified water was used throughout and all other chemicals were of analytical grade.

\subsection{Preparation and characterization of $L N$ incorporating edelfosine}

LN were prepared by the hot homogenization method consisting of high shear homogenization and ultrasonication. Briefly, the lipid phase comprised $300 \mathrm{mg}$ of either Compritol $^{\circledR} 888$ ATO or Precirol ${ }^{\circledR}$ ATO 5 along with $15 \mathrm{mg}$ of edelfosine, while the aqueous phase consisted of $10 \mathrm{~mL}$ of a $2 \%$ Tween $^{\circledR} 80$ aqueous solution. The aqueous phase was heated at $75^{\circ} \mathrm{C}$, in the case of Compritol ${ }^{\circledR} 888$ ATO, or $60^{\circ} \mathrm{C}$, in the case of Precirol ${ }^{\circledR}$ ATO $5\left(5^{\circ} \mathrm{C}\right.$ above the melting point of the lipid) and added to the melted lipid phase at the same temperature. This temperature was maintained during the complete process of the nanoparticle formulation. The mixture was dispersed with the help of a Microson ${ }^{\mathrm{TM}}$ ultrasonic cell disruptor (NY, USA) for 1 minute at an effective power of $10 \mathrm{~W}$. The preformed emulsion was then homogenized in an Ultraturrax ${ }^{\circledR}$ (IKA-Werke, Germany) for 1 minute at 24,000 rpm and sonicated again with the Microson ${ }^{\mathrm{TM}}$ ultrasonic cell disruptor (NY, USA) for 1 minute at $10 \mathrm{~W}$. The nanoparticle suspension was cooled in an ice bath and washed twice with filtered water by diafiltration with Amicon Ultra-15 filters of 10,000 dalton molecular weight cut-off membrane (Millipore ${ }^{\circledR}$, Cork, Ireland) $(4,000 \times \mathrm{g}, 30 \mathrm{~min})$ to remove the excess of surfactant and non-incorporated drug. Nanoparticles were then resuspended in $10 \%$ trehalose solution and kept at $-80{ }^{\circ} \mathrm{C}$ for freeze-drying. These frozen $\mathrm{LN}$ suspensions were introduced into the freeze-dryer, kept at $-50{ }^{\circ} \mathrm{C}$. Once inside the freeze-drier, a slow temperature rising process was performed up to $5{ }^{\circ} \mathrm{C}$, for the sublimation of the solvent. From this point on, temperature was raised to room temperature to evaporate the residual molecules of water. The whole process takes place at reduced pressure $\left(12 \cdot 10^{-3}\right.$ mbar $)$.

Particle size and distribution of the nanoparticles were measured by photon correlation spectroscopy (PCS) using a Zetasizer Nano (Malvern Instruments, UK). Each sample was diluted with distilled water until the appropriate concentration of particles was achieved to avoid multiscattering events. The homogenous suspension obtained was examined to determine the mean volume diameter, size distribution and polydispersity. All measurements were done in triplicate. The surface charge was determined by measuring the zeta potential of LN based on the Smoluchowski equation, using the same equipment.

Edelfosine loading was quantified by an ultra high-performance liquid chromatography tandem mass spectrometry (UHPLC-MS/MS) method previously validated [21]. A sample of $10 \mathrm{mg}$ of lyophilized nanoparticles was dissolved in $1 \mathrm{ml}$ of chloroform and $10 \mu \mathrm{L}$ of the internal standard PAF $(0.2 \mathrm{mg} / \mathrm{mL})$ were then spiked to the samples. Finally, $3 \mathrm{~mL}$ of methanol were added to the mixture. This solution was vortex mixed for $1 \mathrm{~min}$ at room temperature and centrifuged at $20,000 \times g$ for $10 \mathrm{~min}$. Eventually, $2 \mu \mathrm{L}$ aliquots of the supernatant were injected into the chromatographic system. 


\subsection{P-glycoprotein inhibition experiments}

To test the ability of the LN to modulate ATPase activity of membrane located P-gp [22], drug loaded LN made of both lipids were tested and compared to drug loaded LN prepared without Tween ${ }^{\circledR} 80$ with the P-gp drug interaction assay kit (SPIbio ${ }^{\circledR}$, Massy, France). Briefly, this assay is based on the study of modulation of basal or induced ATPase activity from enriched P-gp membrane vesicle preparation. P-gp ATPase activity is measured by a spectrophotometric method based on continuous monitoring of ADP formation, in the vesicle suspension medium.

LN without Tween ${ }^{\circledR} 80$ were prepared like the regular $\mathrm{LN}$, replacing the $10 \mathrm{~mL}$ of a $2 \%$ Tween $^{\circledR} 80$ aqueous solution by $10 \mathrm{~mL}$ of water.

\subsection{Cell growth inhibition studies}

The cytotoxicity of edelfosine-loaded LN against C6 rat glioma cells was measured by MTT assay. Tumor cells were maintained in culture in DMEM supplemented with $10 \%$ heat-inactivated FBS, 100 units $/ \mathrm{mL}$ penicillin and $100 \mathrm{mg} / \mathrm{mL}$ streptomycin, at 37 ${ }^{\circ} \mathrm{C}$ in a humid atmosphere containing $5 \% \mathrm{CO}_{2}$. The cells were seeded in a 96-well plate at a density of 2000 cells per well, and incubated for $24 \mathrm{~h}$. The medium was then replaced with increasing concentrations of free edelfosine, drug-loaded LN (edelfosine concentrations of $0.1,1,5,10,15,20,25,30,40,50$ and $70 \mu \mathrm{g} / \mathrm{ml}$ ) and drug-free $\mathrm{LN}$ (lipid concentration of $0.5 \mathrm{mg} / \mathrm{ml}$, corresponding to an edelfosine concentration of 70 $\mu \mathrm{g} / \mathrm{mL}$ ). Incubation was continued as above for $72 \mathrm{~h}$. All media were then removed and $100 \mu \mathrm{L}$ of MTT solution $(0.5 \mathrm{mg} / \mathrm{mL}$ in DMEM) were added to the wells. The cells were incubated for $3 \mathrm{~h}$. MTT was removed and DMSO was added to dissolve the formazan crystals [23]. The optical density at $570 \mathrm{~nm}$ was determined using a BioRad microplate reader. Untreated cells were taken as control with $100 \%$ viability and cells without addition of MTT were used as blank to calibrate the spectrophotometer to zero absorbance. Triton X-100 $1 \%$ was used as positive control of cytotoxicity. All experiments were performed in triplicate.

\subsection{Animal studies}

All animal studies had previous approval from the Animal Care and Ethics Committee of the University of Navarra and the Université Catholique de Louvain. For biodistribution studies, BALB/c mice $(20 \mathrm{~g})$ were obtained from Harlan Interfauna Ibérica S.L. (Barcelona, Spain). For efficacy studies, NMRI mice (Janvier, Genest St Isle, France) were employed. Animals received a standard diet and water ad libitum. Freeze dried formulations were resuspended in PBS by 1 minute vortexing (JP Selecta, Barcelona, Spain) followed by ultrasound bath (JP Selecta, Barcelona, Spain) for 5 minutes prior to administration.

\subsubsection{Biodistribution studies after oral administration}

A single oral administration of edelfosine-loaded Compritol ${ }^{\circledR}$ or Precirol ${ }^{\circledR}$ LN was given to two BALB/c mice groups (edelfosine concentration of $50 \mathrm{mg} / \mathrm{kg}, n=8$ per group). The endpoint of the experiment was taken as the day after the concentration of edelfosine in plasma reached $0.5 \mu \mathrm{g} / \mathrm{mL}\left(168 \mathrm{~h}\right.$ for Compritol ${ }^{\circledR}$ and $216 \mathrm{~h}$ for Precirol ${ }^{\circledR}$ group). At this time point, blood was collected in EDTA surface-coated tubes and then centrifuged at $2,000 \times g$ for $10 \mathrm{~min}\left(4^{\circ} \mathrm{C}\right)$ to collect plasma $(100 \mu \mathrm{L})$. After sacrifice by cervical dislocation, brain, liver, kidneys and intestine were collected and weighed. Tissues were homogenized in $1 \mathrm{~mL}$ of PBS pH=7.4 using a Mini-bead Beater (BioSpect Products, Inc., Bartelsville, Oklahoma, USA) and centrifuged at $10,000 \times g$ for $10 \mathrm{~min}$. 
All plasma and tissue supernatants were then collected and stored at $-80{ }^{\circ} \mathrm{C}$ until UHPLC-MS/MS analysis was performed [21].

\subsubsection{In vivo tumor growth inhibition study}

Eight-week NMRI mice were subcutaneously inoculated into the back right flank with 1 x $10^{5}$ C6 cells in $100 \mu \mathrm{L}$ of DMEM. The effect of the different treatments on the growth of $\mathrm{C} 6$ was assessed by the measurement of the diameter of the tumors with an electronic caliper every three days using the following equation: $V=D \cdot d^{2} / 2$, where $D$ and $d$ correspond to the longest and shortest diameter of the tumor, respectively. Treatments were initiated when tumors reached $6.0 \pm 0.5 \mathrm{~mm}$ in diameter. Mice were then divided into six groups (9 mice per group): group 1: PBS; group 2: edelfosine solution (30 $\mathrm{mg} / \mathrm{kg}$; dissolved in PBS); group 3: edelfosine-loaded Compritol ${ }^{\circledR} 888$ ATO nanoparticles (edelfosine concentration of $30 \mathrm{mg} / \mathrm{kg}$ ); group 4: edelfosine-loaded Precirol ${ }^{\circledR}$ ATO 5 nanoparticles (edelfosine concentration of $30 \mathrm{mg} / \mathrm{kg}$ ); group 5: blank Compritol $^{\circledR} 888$ ATO nanoparticles $(10 \mathrm{mg} / \mathrm{mL}$ lipid concentration); and group 6: blank Precirol $^{\circledR}$ ATO 5 nanoparticles $(10 \mathrm{mg} / \mathrm{mL}$ lipid concentration). The treatments were administered by oral gavage every three days. Mice were sacrificed when their tumor diameter reached $18.0 \pm 0.5 \mathrm{~mm}$ (30-fold increase in size).

\subsection{Statistical analysis}

Differences in P-gp inhibition studies were measured by Mann Whitney test, while mean values of the tumor sizes of all groups were analyzed by Student's $t$ test using Social Package of Statistical Sciences (SPSS). $\mathrm{IC}_{50}$ values were calculated with GraphPad Prism 5 software using the sigmoidal dose-response function with variable Hill slope. A value of $p<0.05$ was considered to be statistically significant.

\section{Results and discussion}

\subsection{Characterization of edelfosine loaded lipid nanoparticles}

The nanoparticles developed showed moderate edelfosine loading (18.5 and $15 \mu \mathrm{g}$ edelfosine/mg formulation for Compritol ${ }^{\circledR}$ and Precirol ${ }^{\circledR}$, respectively, corresponding to an encapsulation efficiency of $85 \%$ ). The average diameter was $111.2 \pm 3.1 \mathrm{~nm}$ $\left(\right.$ Compritol $\left.^{\circledR} \mathrm{LN}\right)$ and $105.5 \pm 2.5 \mathrm{~nm}\left(\right.$ Precirol $\left.^{\circledR} \mathrm{LN}\right)$, with a PDI below 0.3 in all cases, indicating that LN were homogeneous in size (Table I).

Table I. Physicochemical characteristics of the developed LN (mean $\pm \mathrm{SD}$ ).

\section{LN Size (nm) $\quad$ PDI $\quad \zeta$ Potential $\quad \% E E \quad$ Drug loading $(\mu \mathrm{g}$}

\begin{tabular}{|c|c|c|c|c|c|}
\hline LN & Size (nm) & PDI & $(\mathrm{mV})$ & $\% \mathbf{E E}$ & edelfosine/mg form.) \\
\hline $\begin{array}{c}\text { Drug-free } \\
\text { Compritol }^{\circledR} \text { LN }\end{array}$ & $132.8 \pm 5.5$ & $0.269 \pm 0.033$ & $-30.3 \pm 1.9$ & -- & -- \\
\hline $\begin{array}{c}\text { Drug-loaded } \\
\text { Compritol }^{\circledR} \text { LN }\end{array}$ & $111.2 \pm 3.1$ & $0.271 \pm 0.020$ & $-20.6 \pm 2.1$ & $85.53 \pm 6.92$ & $18.49 \pm 2.77$ \\
\hline $\begin{array}{l}\text { Drug-free } \\
\text { Precirol }^{\circledR} \text { LN }\end{array}$ & $118.9 \pm 2.3$ & $0.246 \pm 0.029$ & $-30.1 \pm 1.1$ & -- & -- \\
\hline $\begin{array}{l}\text { Drug-loaded } \\
\text { Precirol }^{\circledR} \text { LN }\end{array}$ & $105.4 \pm 2.5$ & $0.227 \pm 0.015$ & $-21.6 \pm 3.1$ & $84.62 \pm 4.98$ & $15.31 \pm 3.29$ \\
\hline
\end{tabular}


Figure 1 represents the size distribution of representative formulations of both Compritol $^{\circledR}$ and Precirol ${ }^{\circledR}$ LN. Zeta potential was negative in all cases, around $-21 \mathrm{mV}$ for both types of drug-loaded LN, while drug-free LN presented zeta potential values of $-30 \mathrm{mV}$, meaning that some drug was located on the surface of the nanoparticles, being responsible for the decrease in the zeta potential by leaving less room for Tween ${ }^{\circledR} 80$ to accommodate on the surface of the LN.

A

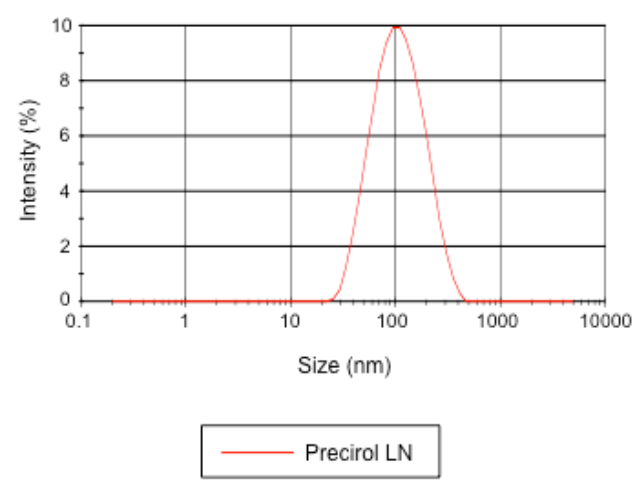

B

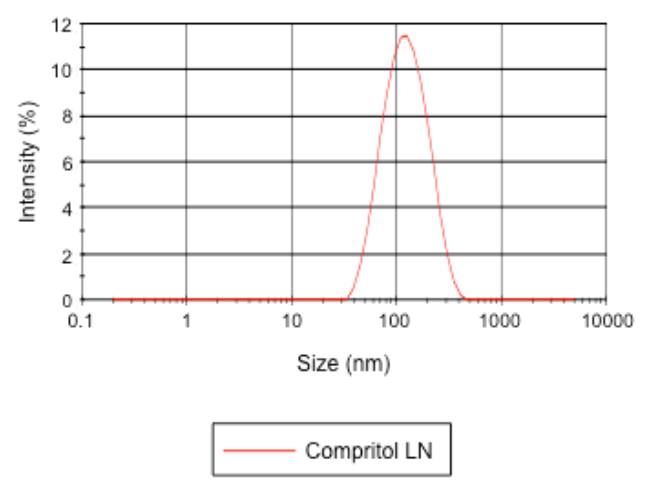

Figure 1. Representative size distribution of edelfosine-loaded A) Precirol $^{\circledR}$ and B) Compritol $^{\circledR}$ LN formulations.

\subsection{Biodistribution study}

In a previous study, the biodistribution patterns of orally administered free edelfosine revealed that the drug was widely scattered in many organs, but only a small amount was found in the brain [17]. However, when edelfosine is orally administered in $\mathrm{LN}$, the biodistribution pattern is altered and accumulation of drug in brain is increased. This change in the biodistribution pattern supports the existence of intact LN in plasma, which later will allow the drug cross the blood brain barrier. Besides, it has been described by Olbrich and Müller [24] that some stabilizers, such as Poloxamer 407 or Tween 80 , distinctly slow down the degradation velocity of the $\mathrm{LN}$, as they provide sterically stabilizing layers of different thicknesses which hamper the anchoring of lipases/colipases and consequently, decrease the degradation velocity. This gives time for the LN to be absorbed. Figure 2 shows how, after the oral administration of edelfosine-loaded Compritol ${ }^{\circledR}$ and Precirol ${ }^{\circledR}$ LN (168 h and $216 \mathrm{~h}$, respectively), edelfosine presents high tissue/plasma ratios of 4.5 and 12.4 for Precirol ${ }^{\circledR}$ and Compritol $^{\circledR}$ LN, respectively, indicating higher accumulation in mouse brain when edelfosine is administered encapsulated in LN. These values are much higher compared to those when edelfosine was administered in solution (tissue/plasma ratio $<0.5$ ) [17]. 


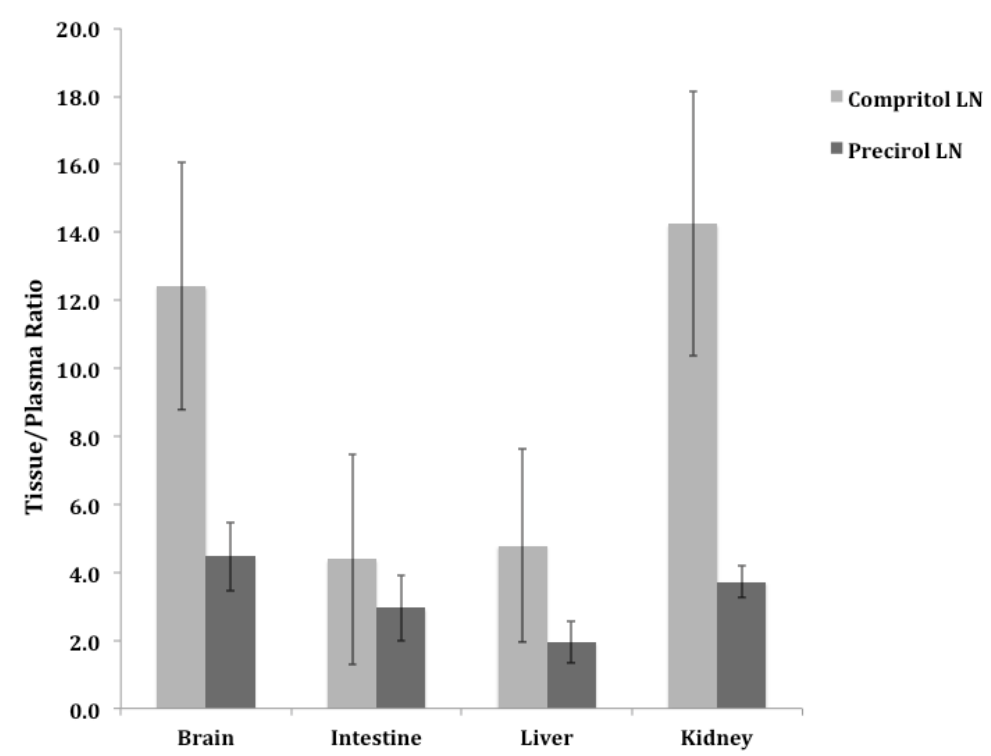

Figure 2. Tissue/plasma concentration ratios of edelfosine after a single oral dose of edelfosine-loaded Compritol $^{\circledR}$ and Precirol ${ }^{\circledR} \mathrm{LN}$ to BALB/c mice $(n=8$ per group, mean $\pm \mathrm{SD}$ ).

\subsection{In vitro studies}

The accumulation of drug in brain tissue when administered into LN is probably due to the inhibition of P-gp by the nanoparticles. To confirm this, a P-gp drug interaction in vitro assay was performed, in which Compritol ${ }^{\circledR}$ and Precirol ${ }^{\circledR}$ LN were tested against P-gp containing membrane vesicles. The P-gp inhibition in an in vitro test system was observed to be particle size and concentration independent. Figure 3 shows how Tween ${ }^{\circledR} 80$ coated Precirol $^{\circledR}$ and Compritol $^{\circledR}$ LN $(150 \mu \mathrm{g} / \mathrm{mL}$ of edelfosine) formulations were found to be more efficient in inhibiting P-gp, significantly decreasing P-gp relative activity compared to that of the baseline activity. On the other hand, LN prepared without Tween ${ }^{\circledR} 80(150 \mu \mathrm{g} / \mathrm{mL}$ of edelfosine $)$ did not decrease the relative activity of P-gp. Furthermore, lower LN concentrations $(15 \mu \mathrm{g} / \mathrm{mL}$ and $1.5 \mu \mathrm{g} / \mathrm{mL}$ of edelfosine loaded LN) were observed still to be able to lower the P-gp activity. All these data confirm that Tween ${ }^{\circledR} 80$ is an essential component in LN for inhibition of the P-gp.

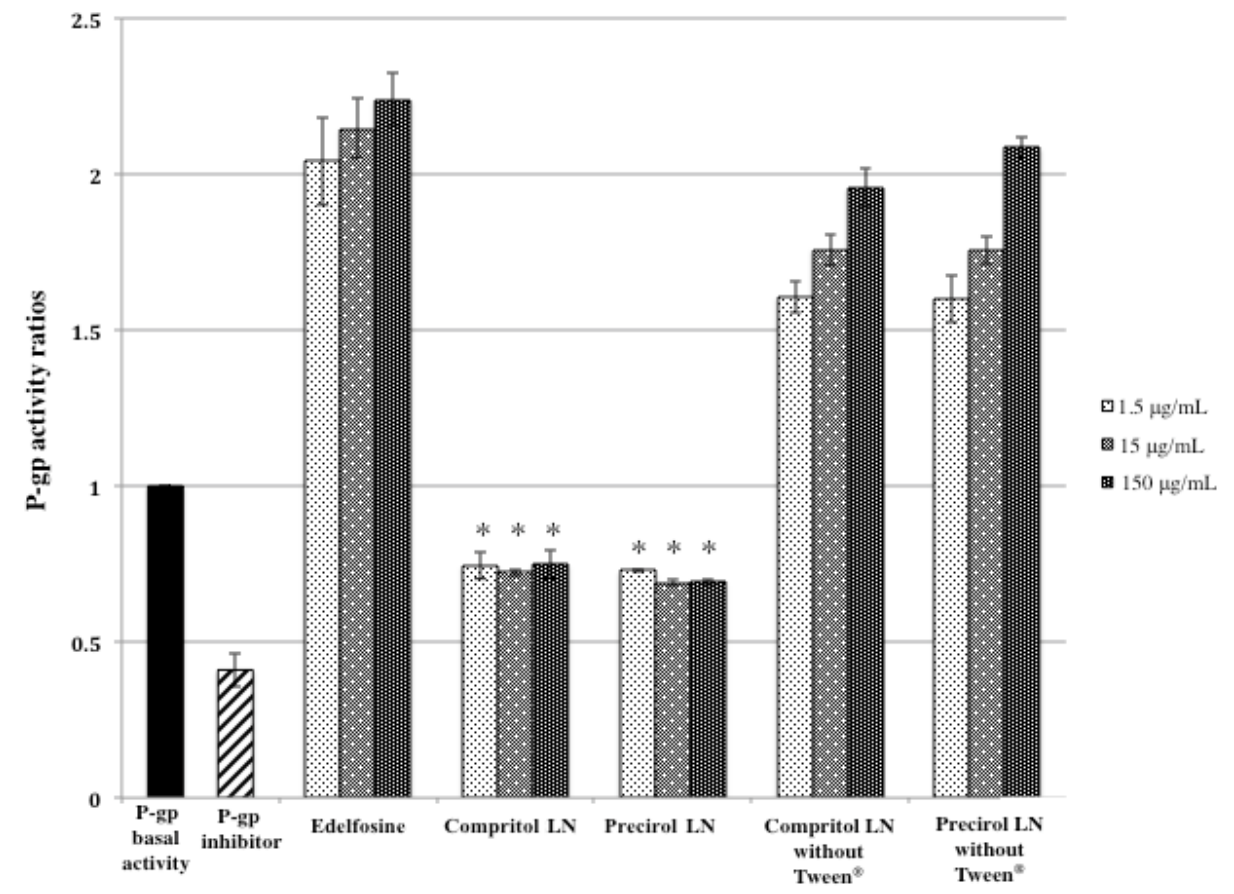


Figure 3. P-gp inhibition experiments with the SPIbio ${ }^{\circledR}$ test system for the different LN formulations and concentrations of edelfosine $(1.5,15$ and $150 \mu \mathrm{g} / \mathrm{mL})$. Comparable standards are given by the baseline activity of the test system with additional results from P-gp inhibitor vinblastine. The baseline activity of the test system itself was taken as 1.0 value. $(n=4$, mean $\pm \mathrm{SD}) * p<0.05$ levels by Mann Whitney's $U$ test compared with baseline ATPase activity of P-gp.

Several studies have recently demonstrated that pharmaceutical excipients which are largely used as inert vehicles in drug formulations, like Cremophor-EL, Triton X100 and Tween ${ }^{\circledR} 80$ are emerging as a special class of P-gp inhibitors [25]. Some of these may even disrupt the function of P-gp and thus enhance the absorption of the drugs that are substrates of P-gp across different barriers. On the other hand, the mechanism by which nanoparticles cross the BBB is still uncertain but depending on the LN composition, the P-gp efflux pump inhibition can be conferred to the LN. For instance, Tween ${ }^{\circledR} 80$ produces changes of membrane fluidity in the cells [26]. More concretely, it contains oxyethylene groups that may change the fluidity of the polar head group regions of cell membranes [27]. The disturbance of this environment might cause changes in secondary and tertiary structure of P-gp, leading to the loss of its function. Besides, the effect of Tween ${ }^{\circledR} 80$ may also result in a negative regulation of the ATPase activity of the P-gp $[9,14]$.

In addition to this, another accepted way by which Tween ${ }^{\circledR} 80$ coated LN are able to cross the BBB implies the adsorption of apolipoproteins (especially ApoE) onto the surface of the LN, so that after being recognized by the low-density lipoprotein (LDL) receptors present in the $\mathrm{BBB}$, they are internalized [28-30]. The adsorption of apolipoproteins onto the nanoparticle surface, along with the solubilization of endothelial cell membrane lipids and membrane fluidization due to surfactant effects of polysorbates, is thought to be responsible for LN uptake in the brain after their adhesion to the endothelial cells of the blood brain barrier [28, 30]. After confirming that LN are able to get through the BBB by means of P-gp inhibition and assuming ApoE adsorption, we aimed to assess the cytotoxicity of edelfosine-loaded LN, and their tumor cell killing activity was determined against the C6 rat glioma cell line by MTT assay. Cytotoxicity was assessed by the comparison of $\mathrm{IC}_{50}$ values of free edelfosine, edelfosine-loaded LN and drug-free LN. The results of the cytotoxicity studies indicate that edelfosine-loaded Compritol ${ }^{\circledR}$ and Precirol ${ }^{\circledR}$ LN significantly reduced $\mathrm{IC}_{50}$ values in a P-gp overexpressing glioma cell line over free drug. Free edelfosine showed a very high $\mathrm{IC}_{50}$ value of $27.5 \mu \mathrm{g} / \mathrm{mL}(55 \mu \mathrm{M})$, suggesting resistance of this cell line to the drug after $72 \mathrm{~h}$ (Figure 4) and, indeed, the disruption of tumor cell membranes, is due to a detergent effect of the molecule, rather than apoptotic, as edelfosine presents an amphiphilic structure $[31,32]$. 


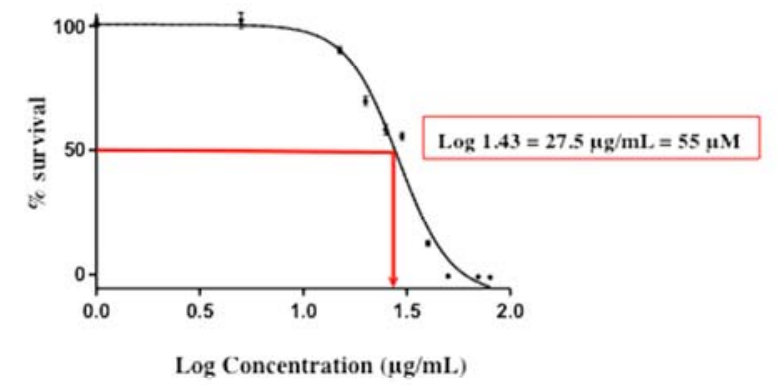

B

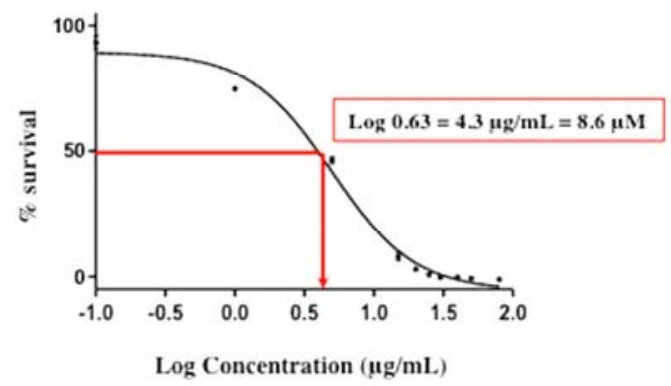

C

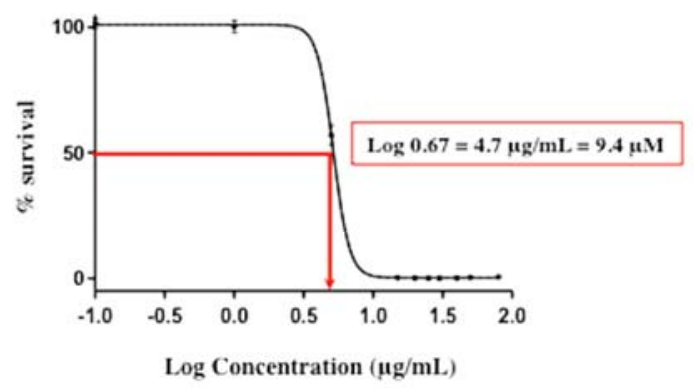

Figure 4. Viability study of $\mathrm{C} 6$ rat glioma cell line $72 \mathrm{~h}$ after the treatment with increasing concentrations of (A) free edelfosine and drug loaded (B) Compritol $^{\circledR}$ and (C) Precirol ${ }^{\circledR} \mathrm{LN}(n=6$, mean $\log$ Concentration $\pm \mathrm{SD})$.

This low drug effectiveness is mainly ascribed to enhanced active efflux of the drug out of the cell, for which P-gp is responsible [33]. However, when edelfosine was incorporated into either Compritol ${ }^{\circledR}$ or Precirol ${ }^{\circledR} \mathrm{LN}$, the $\mathrm{IC}_{50}$ value $72 \mathrm{~h}$ after the treatment decreased dramatically to $4.3 \mu \mathrm{g} / \mathrm{mL}(8.6 \mu \mathrm{M})$ and $4.7 \mu \mathrm{g} / \mathrm{mL}(9.4 \mu \mathrm{M})$, respectively. The intense decrease in the $\mathrm{IC}_{50}$ value is probably due to the small size of LN, making possible an intracellular uptake, and the P-gp inhibiting properties already described, since Tween ${ }^{\circledR} 80$ can inhibit P-gp related drug transport $[19,20]$. Thus, the adjuvant effect of Tween ${ }^{\circledR} 80$ seems to be imperative for high intracellular drug concentration maintenance. Edelfosine-free LN vehicles did not cause cytotoxicity against C6 cell line since the percentage of cell survival was above $85 \%$ (data not shown). The current study therefore suggests that there might be at least two major reasons for enhanced cytotoxicity of edelfosine-loaded LN in P-gp-mediated resistant cells: (a) a possible increased extent of drug uptake by endocytosis of nanoparticles, which helps to partially bypass P-gp; and (b) a decreased efflux rate of drug through inhibition of P-gp function caused by Tween ${ }^{\circledR} 80$, a component of nanoparticles. They both increase intracellular drug concentrations, which is the key to overcoming transporter-mediated resistance [19].

\subsection{In vivo tumor growth inhibition study}

After the in vitro effectiveness of the LN had been confirmed, we evaluated their efficacy in an in vivo xenograft C6 rat glioma bearing mouse model. For that reason, xenograft C6 glioma bearing mice were treated with oral administrations of $30 \mathrm{mg} / \mathrm{kg}$ of edelfosine solution and edelfosine-loaded Compritol ${ }^{\circledR}$ and Precirol ${ }^{\circledR}$ LN every 3 days for 14 days. Tumor growth was followed as a function of time after treatment (Figure 5). In addition, changes in mean body weight were determined as a measure of drug induced toxicity. Regardless of the type of LN used, the therapeutic activity of the 
edelfosine-loaded LN formulations was significantly higher than the edelfosine solution administered at the same dose. Treatments did not show visible toxicity, as a decrease in body weight was not observed in any group (data not shown).

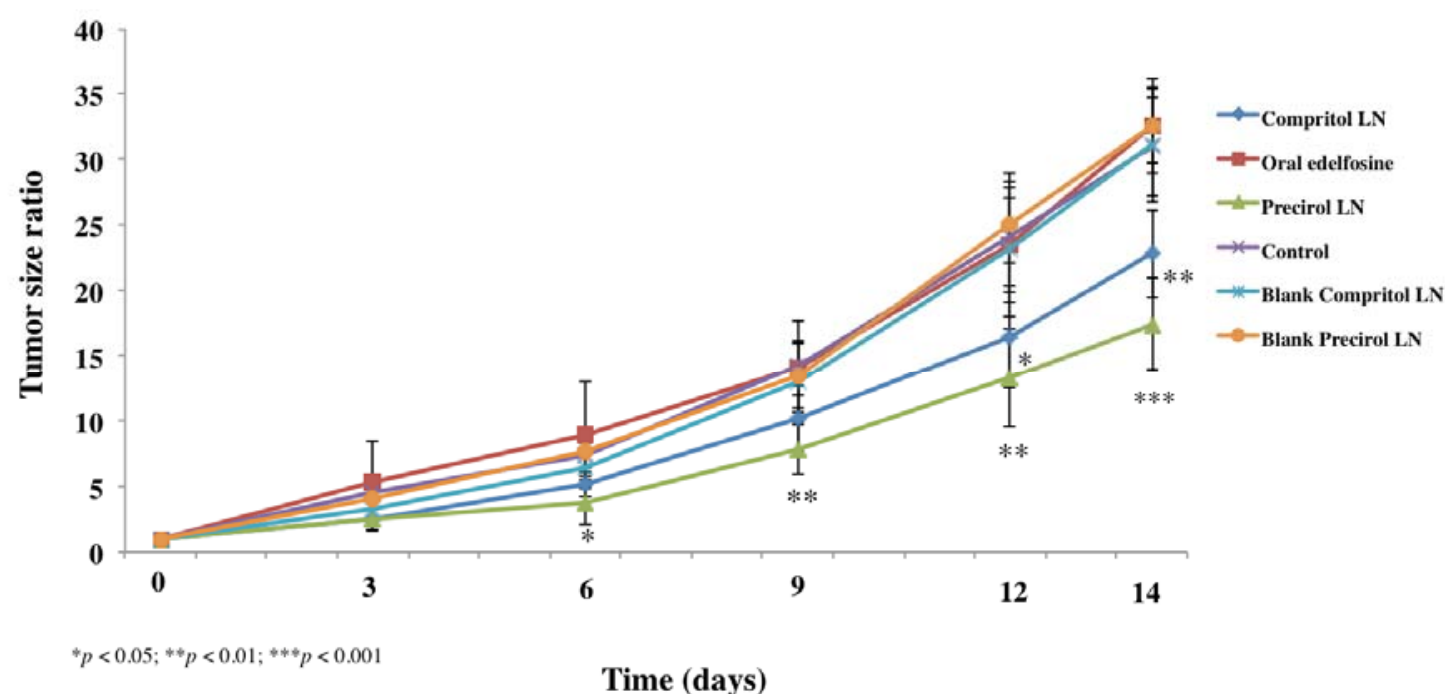

Figure 5. Evolution of tumor growth of xenograft C6 rat glioma implanted in mice, expressed as foldincrease ratio compared to tumor initial size, after treatments with PBS, free edelfosine (30 mg/kg bw), drug loaded LN (30 mg/kg bw) and drug-unloaded LN every three days over the oral route ( $n=9$ per group, mean $\pm \mathrm{SD}$ ). Statistical analysis by Student's $t$ test.

Regarding efficacy, significant differences were observed in tumor regression at day 6, after the third oral dose of edelfosine-loaded LN (Figure 5), compared to the oral administration of the edelfosine solution and the drug-unloaded LN, which did not have any effect on the tumor growth. The tumor burden of edelfosine-loaded LN treated mice was significantly smaller compared with control (PBS), free drug or drug-unloaded LN treated mice. The hypothesis for the mechanism of action of these LN against this xenograft glioma can be attributed to two main issues. First, the inhibition of the P-gp by Tween ${ }^{\circledR} 80$ by the oxyethylene groups that it contains in its molecular structure, which may alter the fluidity of the membrane leading to P-gp disfunction [27]; and second, the release of the drug from the nanoparticles once these are internalized in the cell. The combination of these two effects could be responsible for the high intracellular accumulation of the drug in the tumor, preventing its removal from the cytosol by efflux pump proteins (P-gp).As a result, the consequent increase in drug concentration would permit the onset of tumor cell death.

\section{Conclusions}

In this article, a high accumulation of edelfosine was found in brain tissue when administered in LN, suggesting that these nanocarriers might be useful for the delivery of edelfosine to the brain. Moreover, in vitro studies against C6 cell line showed that edelfosine loaded Compritol ${ }^{\circledR}$ and Precirol ${ }^{\circledR}$ LN were able to revert the resistance of the cell to the drug, due to the inhibition of P-gp by Tween ${ }^{\circledR} 80$. The oral administration of edelfosine-loaded LN to mice every three days decreased tumor growth significantly, when compared to the administration of the same dose of the free drug.

In conclusion, these nanocarriers show promise as a potential effective therapeutic agent in order to treat neoplastic diseases located in brain tissue. 
Acknowledgements: Caja Navarra Foundation, Ibercaja, the Government of Navarra, Department of Health ("Ortiz de Landázuri” fellowship, ref: 63/09), the Spanish Ministry of Science and Innovation (SAF2007-61261, SAF2008-02251, SAF201015547, PCT-090100-2007-27, RD06/0020/1037 from Red Temática de Investigación Cooperativa en Cáncer, Instituto de Salud Carlos III, cofunded by the Fondo Europeo de Desarrollo Regional of the European Union) and University of Navarra (FUN). Ander Estella-Hermoso de Mendoza is supported by a research grant from the Department of Education of the Basque Government (BFI06.37).

\section{References}

[1] W.M. Pardridge, Blood-brain barrier delivery. Drug Discov Today 12(1-2) (2007) 54-61.

[2] N.J. Abbott, A.A. Patabendige, D.E. Dolman, S.R. Yusof, D.J. Begley, Structure and function of the blood-brain barrier. Neurobiol Dis 37(1) (2010) 13-25.

[3] A.M. Palmer, The blood-brain barrier. Neurobiol Dis 37(1) (2010) 1-2.

[4] P. Blasi, S. Giovagnoli, A. Schoubben, M. Ricci, C. Rossi, Solid lipid nanoparticles for targeted brain drug delivery. Adv Drug Deliv Rev 59(6) (2007) 454477.

[5] W.M. Pardridge, Brain drug development and brain drug targeting. Pharm Res 24(9) (2007) 1729-1732.

[6] W.M. Pardridge, Drug targeting to the brain. Pharm Res 24(9) (2007) 17331744.

[7] W.M. Pardridge, Blood-brain barrier delivery of protein and non-viral gene therapeutics with molecular Trojan horses. J Control Release 122(3) (2007) 345-348.

[8] S. Gururangan, H.S. Friedman, Innovations in design and delivery of chemotherapy for brain tumors. Neuroimaging Clin. N. Am. 12(4) (2002) 583-597.

[9] W. Loscher, H. Potschka, Blood-brain barrier active efflux transporters: ATPbinding cassette gene family. NeuroRx 2(1) (2005) 86-98.

[10] P. Kleihues, W. Cavanee, in: P. Kleihues and W. Cavanee (Eds.), WHO classification of tumors. Pathology and genetics., IARC press, Lyon, 2000.

[11] H. Bolhuis, H.W. van Veen, B. Poolman, A.J. Driessen, W.N. Konings, Mechanisms of multidrug transporters. FEMS Microbiol Rev 21(1) (1997) 55-84.

[12] L. Cerveny, P. Pavek, J. Malakova, F. Staud, Z. Fendrich, Lack of interactions between breast cancer resistance protein (bcrp/abcg2) and selected antiepileptic agents. Epilepsia 47(3) (2006) 461-468.

[13] M. Maliepaard, M.A. van Gastelen, A. Tohgo, F.H. Hausheer, R.C. van Waardenburg, L.A. de Jong, D. Pluim, J.H. Beijnen, J.H. Schellens, Circumvention of breast cancer resistance protein (BCRP)-mediated resistance to camptothecins in vitro using non-substrate drugs or the BCRP inhibitor GF120918. Clin Cancer Res 7(4) (2001) 935-941.

[14] A. Beduneau, F. Hindre, A. Clavreul, J.C. Leroux, P. Saulnier, J.P. Benoit, Brain targeting using novel lipid nanovectors. J. Control. Rel. 126(1) (2008) 44-49.

[15] M.F. Bennewitz, W.M. Saltzman, Nanotechnology for delivery of drugs to the brain for epilepsy. Neurotherapeutics 6(2) (2009) 323-336.

[16] M.L. Bondi, E.F. Craparo, G. Giammona, F. Drago, Brain-targeted solid lipid nanoparticles containing riluzole: preparation, characterization and biodistribution. Nanomedicine (Lond) 5(1) (2010) 25-32. 
[17] A. Estella-Hermoso de Mendoza, M.A. Campanero, J. de la Iglesia-Vicente, C. Gajate, F. Mollinedo, M.J. Blanco-Prieto, Antitumor alkyl ether lipid edelfosine: tissue distribution and pharmacokinetic behavior in healthy and tumor-bearing immunosuppressed mice. Clin. Cancer Res. 15(3) (2009) 858-864.

[18] A. Estella-Hermoso de Mendoza, B. Lasa-Saracibar, M.A. Campanero, M. Blanco-Prieto, Lipid nanoparticles in biomedicine. in: H. S. Naiwa (Ed.), Encyclopedia of Nanoscience and Nanotechnology 15 (2010) 455-478.

[19] P.P. Constantinides, K.M. Wasan, Lipid formulation strategies for enhancing intestinal transport and absorption of P-glycoprotein (P-gp) substrate drugs: in vitro/in vivo case studies. J Pharm Sci 96(2) (2007) 235-248.

[20] B.D. Rege, J.P. Kao, J.E. Polli, Effects of nonionic surfactants on membrane transporters in Caco-2 cell monolayers. Eur J Pharm Sci 16(4-5) (2002) 237-246.

[21] A. Estella-Hermoso de Mendoza, M.A. Campanero, F. Mollinedo, M.J. BlancoPríeto, Comparative study of A HPLC-MS assay versus an UHPLC-MS/MS for antitumoral alkyl lysophospholipid edelfosine determination in both biological samples and in lipid nanoparticulate systems. J. Chromatogr. B Analyt. Technol. Biomed. Life Sci. 877 (2009) 4035-4041.

[22] A. Garrigues, J. Nugier, S. Orlowski, E. Ezan, A high-throughput screening microplate test for the interaction of drugs with P-glycoprotein. Anal Biochem 305(1) (2002) 106-114.

[23] T. Mosmann, Rapid colorimetric assay for cellular growth and survival: application to proliferation and cytotoxicity assays. J Immunol Methods 65(1-2) (1983) 55-63.

[24] C. Olbrich, R.H. Muller, Enzymatic degradation of SLN-effect of surfactant and surfactant mixtures. Int. J. Pharm. 180(1) (1999) 31-39.

[25] M.V. Varma, Y. Ashokraj, C.S. Dey, R. Panchagnula, P-glycoprotein inhibitors and their screening: a perspective from bioavailability enhancement. Pharmacol Res 48(4) (2003) 347-359.

[26] P.K. Dudeja, K.M. Anderson, J.S. Harris, L. Buckingham, J.S. Coon, Reversal of multidrug resistance phenotype by surfactants: relationship to membrane lipid fluidity. Arch. Biochem. Biophys. 319(1) (1995) 309-315.

[27] E.D. Hugger, B.L. Novak, P.S. Burton, K.L. Audus, R.T. Borchardt, A comparison of commonly used polyethoxylated pharmaceutical excipients on their ability to inhibit P-glycoprotein activity in vitro. J Pharm Sci 91(9) (2002) 1991-2002.

[28] Y. Chen, G. Dalwadi, H.A. Benson, Drug delivery across the blood-brain barrier. Curr. Drug Deliv. 1(4) (2004) 361-376.

[29] T.M. Goppert, R.H. Muller, Polysorbate-stabilized solid lipid nanoparticles as colloidal carriers for intravenous targeting of drugs to the brain: comparison of plasma protein adsorption patterns. J. Drug Target. 13(3) (2005) 179-187.

[30] J. Kreuter, Nanoparticulate systems for brain delivery of drugs. Adv. Drug Deliv. Rev. 47(1) (2001) 65-81.

[31] W.J. van Blitterswijk, M. Verheij, Anticancer alkylphospholipids: mechanisms of action, cellular sensitivity and resistance, and clinical prospects. Curr. Pharm. Des. 14(21) (2008) 2061-2074.

[32] C. Gajate, F. Mollinedo, Biological activities, mechanisms of action and biomedical prospect of the antitumor ether phospholipid ET-18-OCH3 (edelfosine), a proapoptotic agent in tumor cells. Curr. Drug. Metab. 3(5) (2002) 491-525.

[33] G.B. Henderson, B.P. Strauss, Evidence for cAMP and cholate extrusion in C6 rat glioma cells by a common anion efflux pump. J Biol Chem 266(3) (1991) 16411645 . 


\section{Figure Legends}

Figure 1. Representative size distribution of edelfosine-loaded A) Precirol ${ }^{\circledR}$ and B) Compritol $^{\circledR} \mathrm{LN}$ formulations.

Figure 2. Tissue/plasma concentration ratios of edelfosine after a single oral dose of edelfosine-loaded Compritol ${ }^{\circledR}$ and Precirol ${ }^{\circledR}$ LN to BALB/c mice ( $n=8$ per group, mean $\pm \mathrm{SD})$.

Figure 3. P-gp inhibition experiments with the SPIbio ${ }^{\circledR}$ test system for the different LN formulations and concentrations of edelfosine $(1.5,15$ and $150 \mu \mathrm{g} / \mathrm{mL})$. Comparable standards are given by the baseline activity of the test system with additional results from P-gp inhibitor vinblastine. The baseline activity of the test system itself was taken as 1.0 value. $(n=4$, mean $\pm \mathrm{SD}) * p<0.05$ levels by Mann Whitney's $U$ test compared with baseline ATPase activity of P-gp.

Figure 4. Viability study of C6 rat glioma cell line $72 \mathrm{~h}$ after the treatment with increasing concentrations of (A) free edelfosine and drug loaded (B) Compritol ${ }^{\circledR}$ and (C) Precirol ${ }^{\circledR} \mathrm{LN}(n=6$, mean log Concentration \pm SD).

Figure 5. Evolution of tumor growth of $\mathrm{C} 6$ rat glioma implanted in mice, expressed as fold-increase ratio compared to tumor initial size, after treatments with PBS, free edelfosine (30 mg/kg bw), drug loaded LN (30 mg/kg bw) and drug-unloaded LN every three days over the oral route $(n=9$ per group, mean \pm SD). Statistical analysis by Student's $t$ test. 